\title{
Frequency-Following Response and Auditory Behavior in Children with Prenatal Exposure to the Zika Virus
}

\author{
Laís Cristine Delgado da Hora1(1) Lilian Ferreira Muniz ${ }^{10}$ Silvana Maria Sobral Griz ${ }^{10}$ \\ Jéssica Dayane da Silva ${ }^{2(1)}$ Diana Babini Lapa de Albuquerque Britto ${ }^{10}$ \\ Leonardo Gleygson Angelo Venâncio ${ }^{2(0)}$ Demócrito de Barros Miranda Filho ${ }^{3(0)}$ \\ Mariana de Carvalho Leal ${ }^{4}{ }^{\circ}$
}

1 Department of Speech, Language and Audiology, Universidade

Federal de Pernambuco, Recife, PE, Brazil

${ }^{2}$ Graduate Program in Human Communication Health, Universidade Federal de Pernambuco, Recife, PE, Brazil

${ }^{3}$ Medical Sciences College, Universidade de Pernambuco, Recife, PE, Brazil

${ }^{4}$ Department of Surgery, Universidade Federal de Pernambuco,

Recife, PE, Brazil

Int Arch Otorhinolaryngol 2022;26(3):e380-e389.

\author{
Address for correspondence Laís Cristine Delgado da Hora, M.Sc. \\ Department of Speech, Language and Audiology, Universidade \\ Federal de Pernambuco. Avenida Artur de Sá, s/n, Cidade \\ Universitária, Recife (PE) 50670-420, Brazil \\ (e-mail: delgado.lais@gmail.com).
}

\begin{abstract}
Keywords

- zika virus

- microcephaly

- surveys and questionnaires

- frequency-following response

- speech-evoked auditory brainstem response

- evoked potentials

- auditory brain stem

Introduction Prenatal exposure to the Zika virus can impair neurodevelopment and cause auditory damage.

Objective To analyze the frequency-following response (FFR) and the auditory behavior (with the LittlEars ${ }^{\circledR}$ questionnaire) of children with and without prenatal exposure to Zika virus infection.

Methods A total of 30 children participated in the present study, divided into 3 groups: 10 children with microcephaly and prenatal exposure to the Zika virus; 10 normocephalic children with prenatal exposure to the Zika virus; and 10 children with no evidence of prenatal exposure to the virus. The FFR test was performed with the /da/ syllable. The LittlEars ${ }^{\circledR}$ questionnaire was used with parents/guardians.

Results For the FFR measurements, there was no difference between the groups. The children with exposure to the Zika virus presented a final score in the questionnaire below what is expected from children with normal hearing. A significant difference was observed for the final, semantic, and expressive scores between the group with microcephaly and the other groups. A strong negative correlation was seen between the LittlEars ${ }^{\circledR}$ questionnaire final score and the FFR measurements for the group with microcephaly when compared with the other groups.

Conclusion Children exposed to the Zika virus, with and without microcephaly, presented FFR patterns similar to what was seen in children with no evidence of virus exposure. However, they showed signs of immature auditory behavior, suggesting auditory development delay.
\end{abstract}

received

August 10, 2020

accepted

December 1, 2020

published online

November 3, 2021
DOI https://doi.org/ $10.1055 / \mathrm{s}-0041-1726048$ ISSN 1809-9777.

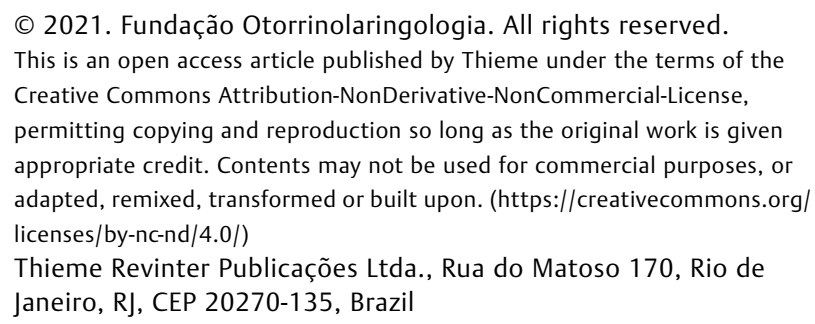

(C) 2021. Fundação Otorrinolaringologia. All rights reserved. This is an open access article published by Thieme under the terms of the Creative Commons Attribution-NonDerivative-NonCommercial-License, permitting copying and reproduction so long as the original work is given appropriate credit. Contents may not be used for commercial purposes, or adapted, remixed, transformed or built upon. (https://creativecommons.org/ licenses/by-nc-nd/4.0/) Thieme Revinter Publicações Ltda., Rua do Matoso 170, Rio de Janeiro, RJ, CEP 20270-135, Brazil 


\section{Introduction}

Prenatal exposure to the Zika virus can impair multiple child neurodevelopmental. The profile of the virus is strongly neurotropic, affecting neural progenitor and neuronal cells in all stages of maturation. ${ }^{1,2}$

The congenital syndrome associated with Zika virus infection (ZCS) is characterized by developmental changes related to prenatal exposure to Zika virus infection. A wide range of signs and symptoms are associated with this syndrome, such as anatomical central nervous system (CNS) anomalies (microcephaly), and secondary functional impairment. ${ }^{1,3-5}$

Children who had been exposed to Zika virus infection in the intrauterine period and were born normocephalic are also at risk of neurodevelopmental changes. The evolutive reports in this group show changed results in the long run regarding the neurological development of different domains, including those of cognition and language/communication. ${ }^{6-9}$

Auditory changes were described, associated with prenatal exposure to Zika virus infection. ${ }^{10}$ In 2019 , The Joint Committee on Infant Hearing included prenatal Zika virus exposure as a high-risk criterium for hearing loss and referred to neonatal hearing screening and auditory follow-up, among the other risk indicators. ${ }^{11}$

Hearing screening failures in the otoacoustic emissions (OAE) and auditory brainstem response to click stimulus (ABR-click) and the presence of sensorineural hearing loss are the most common audiological findings in children prenatally exposed to Zika virus infection. ${ }^{12}$ Nonetheless, due to the neurotropic profile of the Zika virus and to the changes in the CNS resulting from the infection, damages to the central auditory pathways potentially impacting the central auditory development and processing cannot be discarded. $^{12-14}$

Cortical malformations and neurodevelopmental disorders can alter the maturation development of peripheral and central auditory pathways, such as sound information processing, which, in turn, can also impact language and communication development. ${ }^{15-17}$

Assessing and monitoring auditory function in children exposed to the Zika virus with several testings might lead to proper diagnosis and early interventions. ${ }^{12,13}$

Speech stimulus ABR, known as frequency-following response (FFR), might be used to understand how the auditory pathway decodes verbal sounds, starting at the brainstem level - the anatomical site where the perception of speech sounds begins. ${ }^{18}$ Frequency-following response has been widely studied, as it involves the auditory perception of speech, having the potential to be a sensitive biological marker of communication disorders. ${ }^{19}$

Auditory questionnaires and checklists help to monitor changes in the auditory development function, especially in auditory skills early in childhood. ${ }^{20,21}$ The LittlEars $^{\circledR}$ auditory questionnaire (LEAQ) has proven to be a simple and reliable instrument that gives information about auditory development and skills based on the observation of the parents/guardians of the auditory behavior of children in daily situations. ${ }^{22,23}$

Given the evidence of CNS changes and the risk of auditory damage, a better understanding of electrophysiological and behavioral auditory function in children is needed. The present study aimed to analyze FFR findings and auditory behavior of children with prenatal exposure to Zika virus infection, with and without microcephaly, and to compare these findings with children without evidence of prenatal exposure and with typical development.

\section{Materials and Methods}

The present observational, cross-sectional study is related to an original project entitled "Audiological Assessment of Children with Suspicion for Congenital Infection with the Zika Virus," approved by the Research Ethics Committee under no. 3.072.730. It was conducted in a reference public hospital in the state of Pernambuco, Brazil, between July 2019 and February 2020. The parents/guardians were informed of its objectives and procedures, and signed an informed consent form.

Thirty children born between 2015 and 2016 (the period following the Zika virus epidemic in Pernambuco), of both genders and with no evidence of peripheral hearing loss participated in the research. From those, 20 were recruited after assessment in the original project, and 10 were recruited only for the present study. The children were distributed in three groups, according to the following criteria:

i. Group 1 (microcephalic) - 10 children with confirmed laboratory diagnosis of prenatal exposure to Zika virus infection (positive molecular/serological test of the child with real-time polymerase chain reaction [RT-PCR] or immunoglobulin M [IgM] through enzyme-linked immunosorbent assay [ELISA) and with microcephaly (head circumference $<-2$ standard deviations (SDs) for age and gender, according to the InterGrowth reference curves recommended by the World Health OrganizationWHO, ${ }^{24}$ aged between 39 and 51 months old (mean: $45 \pm 4$ months old), pass in neonatal hearing screening (conducted with the ABR-click), monitoring with ABR-click at $35 \mathrm{~dB} \mathrm{nHL}$, and no evidence of hearing loss.

ii. Group 2 (normocephalic) - 10 children with confirmed laboratory diagnosis, possible or presumed prenatal exposure to the Zika virus infection (epidemiologic history, clinical changes compatible with infection, or positive molecular/serological test of the mother and/or child with RT-PCR or IgM through ELISA, normocephalic, aged between 36 and 46 months old (mean: $40 \pm 4$ months old), pass in neonatal hearing screening (conducted with the ABR-click), monitoring with ABR-click at $35 \mathrm{~dB} \mathrm{nHL}$, and no evidence of hearing loss.

iii. Group 3 (not exposed) - 10 children with typical development, with no evidence of prenatal exposure to Zika virus infection or other prenatal infections, with no 
neurological impairments, no otologic symptoms, no audiological complaints that interfere in hearing/ comprehension of speech, no evidence of hearing loss, no complaints/signs of change in language, aged between 42 and 55 months old (mean $49 \pm 5$ months old), with pass in the neonatal hearing screening (with the $\mathrm{OAE}$ and/or ABR) and normal ABR-click.

Initially, information about the children with prenatal exposure to Zika virus infection, regarding the diagnosis of the infection, the severity of the microcephaly, result of the neonatal hearing screening, and results of the audiological monitoring was selected from the original database study.

On the day of the assessment, the parents/guardians of the children answered questions from an interview form developed and administered by the researchers. Information on the health history and previous development of the child, including hearing and language, was collected to attend eligibility criteria and also to characterize the sample.

Otoscopy and acoustic immittance was performed (AT model, Interacoustics, Middelfart, Denmark) to eliminate external and middle ear disorders. Only a type A tympanometric curve (admittance peak at between 0.3 and $1.6 \mathrm{ml}$ and pressure peak at between - 100 and +100 decapascals [daPa]) and presence of ipsi and contralateral acoustic reflexes was accepted.

According to the data obtained in the interview and auditory screening, children with reported viral congenital infection, other congenital syndromes, with any auditory risk factors (according to the Joint Committee on Infant Hearing, 2019), and with signs of changes in the peripheral auditory pathways were excluded.

The parents of all the children included in the study answered the LEAQ, administered as an interview. The 35 questions were read by the researchers, and the parents/guardians were given the option of orally answering "yes" or "no." In case they did not understand the question, the researcher exemplified situations, as suggested by the questionnaire itself. The individual final score was calculated considering all the "yes" answers given by the respondents.

The questions in the LEAQ can be divided into 3 auditory behavior categories: receptive auditory behavior (questions $0-7$ ), semantic auditory behavior (questions 8-20, 22-24, $27,30,33$, and 34), and expressive language (questions 21 , $25,26,28,29,31,32,35)$. An individual score was calculated for each child, considering all "yes" answers to verify the performance of the child in each area. ${ }^{25}$ The individual final score and the mean of the final scores of the groups were compared with the reference values for children with normal hearing, which considers a score $\geq 33$ for children $>24$ months old (minimum value of 25 , according to the confidence interval $[\mathrm{CI}]$ ) - that is, presence of at least 33 of the 35 behaviors listed in the questionnaire. ${ }^{22}$

For FFR assessment, the SmartEP equipment (Intelligent Hearing Systems, Miami, FL, USA) was used. The skin of the child was prepared, and electrodes were placed as follows: two negative electrodes at A1 and A2; one positive electrode at Fz; and the ground electrode at Fp2. The children were alert, placed in a reclined chair. Children with microcephaly who had no postural stability sat on the lap of the parent/guardian. All participants were given the option to watch silent videos in a tablet.

The alternate /da/ syllable stimulus with 40 milliseconds (ms) was monaurally (only in the right ear) presented via ER3 insert earphones at $75 \mathrm{~dB} \mathrm{HL}$, and at a presentation rate of 3.77 stimuli per second. The impedance of the electrodes was kept lower than $1 \mathrm{kohms}$, and two replicated waves of 2.000 sweeps each were obtained and added (final wave with 4.000 sweeps), recording window of $70 \mathrm{~ms}$, band-pass filter between 50 and $3000 \mathrm{~Hz}$.

The positive peak wave $\mathrm{V}$ was identified, as well as negative peak waves $\mathrm{A}, \mathrm{C}, \mathrm{D}, \mathrm{E}, \mathrm{F}$, and $\mathrm{O}$. The latency (ms) and amplitude $(\mu \mathrm{V})$ of each wave were measured, and the slope $(\mu \mathrm{V} / \mathrm{ms})$ and area ( $\mu \mathrm{V} \mathrm{X}$ ms) of the VA complex were calculated. All exams were blinded and were analyzed by two examiners with expertise in FFR assessment.

The results were analyzed with the IBM SPSS Statistics, version 20.0 (IBM Corp., Armonk, NY, USA) software, and the $5 \%$ significance level was adopted. The normality of the samples was verified with the Shapiro-Wilk test. To verify the presence of statistical differences between the groups for the FFR measures and LEAQ scores, the parametric one-way analysis of variance (ANOVA) and the nonparametric Kruskal-Wallis test were used, according to the normality of each variable. Then, Levene statistics were used, as well as the Bonferroni post-hoc test (in the variables with normal sample), besides the one-way ANOVA post-hoc test (for variables with non-normal sample). The Pearson correlation test, applied to the variables with a normal sample, was used to verify the existence of a linear relationship between the FFR variables and the LEAQ scores. When the association of the variables had a nonlinear relationship, the Spearman correlation test was used to detect the degree of association between them.

\section{Results}

From 30 children, 17 (56.7\%) were females and 13 (43.3\%) were males. In the group of children with microcephaly, 7 (70\%) had severe microcephaly (head circumference $[\mathrm{HC}]<3$ SDs for age and gender, according to the InterGrowth reference curves. ${ }^{24}$ All children with microcephaly (100\%) had language development delays. In the group of normocephalic children exposed to the Zika virus infection, 8 (80\%) had language complaints/signs of disorders.

Frequency-following response analyses showed no statistically significant difference between all groups for latency and amplitude measures of waves V, A, C, D, E, F, and O, and for the slope and area of the VA complex measures ( - Tables 1, 2, and 3). - Fig. 1 shows the average waveforms of the FFR exam in the studied groups.

For the LEAQ, no child in the microcephaly group (100\%) achieved the minimum final score recommended by the questionnaire for children with normal hearing. Only 5 of the normocephalic children exposed to the Zika virus (50\%) achieved the expected values. All children in the group with 
Table 1 Comparison of the latency measures of the frequency-following response between children with congenital Zika virus infection, with and without microcephaly, and children with no evidence of exposure

\begin{tabular}{|c|c|c|c|c|c|}
\hline Waves & Groups & Mean and SD (ms) & $\mathrm{L} \mathrm{Cl}$ & $\mathrm{H} \mathrm{Cl}$ & $p$-value \\
\hline $\mathrm{V}$ & $\begin{array}{l}\text { Microcephalic } \\
\text { Normocephalic } \\
\text { Not exposed }\end{array}$ & $\begin{array}{l}7.03 \pm 0.82 \\
7.20 \pm 0.59 \\
6.67 \pm 0.37\end{array}$ & $\begin{array}{l}6.50 \\
6.83 \\
6.44\end{array}$ & $\begin{array}{l}13.60 \\
14.03 \\
13.11\end{array}$ & $0.123^{\mathrm{a}}$ \\
\hline $\bar{A}$ & $\begin{array}{l}\text { Microcephalic } \\
\text { Normocephalic } \\
\text { Not exposed }\end{array}$ & $\begin{array}{l}9.46 \pm 0.78 \\
8.96 \pm 0.83 \\
9.01 \pm 0.79\end{array}$ & $\begin{array}{l}8.03 \\
7.30 \\
7.85\end{array}$ & $\begin{array}{l}10.82 \\
9.95 \\
10.32\end{array}$ & $0.327^{b}$ \\
\hline $\mathrm{C}$ & $\begin{array}{l}\text { Microcephalic } \\
\text { Normocephalic } \\
\text { Not exposed }\end{array}$ & $\begin{array}{l}17.76 \pm 1.29 \\
17.57 \pm 0.86 \\
17.26 \pm 1.37 \\
\end{array}$ & $\begin{array}{l}16.52 \\
16.40 \\
14.88 \\
\end{array}$ & $\begin{array}{l}20.18 \\
18.75 \\
18.98 \\
\end{array}$ & $0.677^{\mathrm{b}}$ \\
\hline D & $\begin{array}{l}\text { Microcephalic } \\
\text { Normocephalic } \\
\text { Not exposed }\end{array}$ & $\begin{array}{l}24.36 \pm 1.05 \\
23.86 \pm 0.62 \\
24.36 \pm 0.84\end{array}$ & $\begin{array}{l}23.15 \\
22.95 \\
22.95\end{array}$ & $\begin{array}{l}26.45 \\
24.73 \\
25.98\end{array}$ & $0.336^{\mathrm{b}}$ \\
\hline$E$ & $\begin{array}{l}\text { Microcephalic } \\
\text { Normocephalic } \\
\text { Not exposed }\end{array}$ & $\begin{array}{l}32.82 \pm 0.95 \\
32.07 \pm 1.23 \\
32.77 \pm 0.97\end{array}$ & $\begin{array}{l}31.45 \\
29.40 \\
31.45 \\
\end{array}$ & $\begin{array}{l}34.30 \\
33.70 \\
34.23 \\
\end{array}$ & $0.228^{\mathrm{b}}$ \\
\hline$F$ & $\begin{array}{l}\text { Microcephalic } \\
\text { Normocephalic } \\
\text { Not exposed }\end{array}$ & $\begin{array}{l}41.17 \pm 1.49 \\
40.69 \pm 1.12 \\
41.36 \pm 0.92\end{array}$ & $\begin{array}{l}38.40 \\
38.33 \\
40.10\end{array}$ & $\begin{array}{l}43.60 \\
42.23 \\
42.48\end{array}$ & $0.463^{b}$ \\
\hline 0 & $\begin{array}{l}\text { Microcephalic } \\
\text { Normocephalic } \\
\text { Not exposed }\end{array}$ & $\begin{array}{l}49.48 \pm 0.94 \\
49.53 \pm 0.89 \\
49.32 \pm 0.67\end{array}$ & $\begin{array}{l}48.02 \\
48.42 \\
48.70\end{array}$ & $\begin{array}{l}50.80 \\
51.48 \\
50.88\end{array}$ & $0.847^{b}$ \\
\hline
\end{tabular}

Abbreviations: $\mathrm{HCl}$, higher confidence interval; $\mathrm{LCl}$, lower confidence interval; SD, standard deviation.

${ }^{a}$ Kruskal-Wallis test.

bone-way ANOVA test.

Table 2 Comparison of the amplitude measures in the frequency-following response between children with congenital infection with the Zika virus, with and without microcephaly, and children with no evidence of exposure

\begin{tabular}{|c|c|c|c|c|c|}
\hline Waves & Groups & Mean and SD $(\mu \mathrm{V})$ & $\mathrm{L} \mathrm{Cl}$ & $\mathrm{H} \mathrm{Cl}$ & p-value \\
\hline $\mathrm{V}$ & $\begin{array}{l}\text { Microcephalic } \\
\text { Normocephalic } \\
\text { Not exposed }\end{array}$ & $\begin{array}{l}0.25 \pm 0.34 \\
0.11 \pm 0.08 \\
0.09 \pm 0.06\end{array}$ & $\begin{array}{l}0.04 \\
0.06 \\
0.05\end{array}$ & $\begin{array}{l}0.46 \\
0.16 \\
0.13\end{array}$ & $0.553^{a}$ \\
\hline A & $\begin{array}{l}\text { Microcephalic } \\
\text { Normocephalic } \\
\text { Not exposed }\end{array}$ & $\begin{array}{l}0.36 \pm 0.33 \\
0.26 \pm 0.18 \\
0.22 \pm 0.22\end{array}$ & $\begin{array}{l}0.16 \\
0.15 \\
0.08\end{array}$ & $\begin{array}{l}0.56 \\
0.37 \\
0.36\end{array}$ & $0.400^{\mathrm{a}}$ \\
\hline C & $\begin{array}{l}\text { Microcephalic } \\
\text { Normocephalic } \\
\text { Not exposed }\end{array}$ & $\begin{array}{l}0.13 \pm 0.08 \\
0.10 \pm 0.04 \\
0.08 \pm 0.04\end{array}$ & $\begin{array}{l}0.08 \\
0.08 \\
0.06\end{array}$ & $\begin{array}{l}0.18 \\
0.12 \\
0.10\end{array}$ & $0.281^{\mathrm{a}}$ \\
\hline D & $\begin{array}{l}\text { Microcephalic } \\
\text { Normocephalic } \\
\text { Not exposed }\end{array}$ & $\begin{array}{l}0.34 \pm 0.27 \\
0.24 \pm 0.16 \\
0.15 \pm 0.14\end{array}$ & $\begin{array}{l}0.17 \\
0.14 \\
0.06\end{array}$ & $\begin{array}{l}0.51 \\
0.34 \\
0.24\end{array}$ & $0.191^{\mathrm{a}}$ \\
\hline$E$ & $\begin{array}{l}\text { Microcephalic } \\
\text { Normocephalic } \\
\text { Not exposed }\end{array}$ & $\begin{array}{l}0.30 \pm 0.28 \\
0.19 \pm 0.10 \\
0.16 \pm 0.11\end{array}$ & $\begin{array}{l}0.13 \\
0.13 \\
0.09\end{array}$ & $\begin{array}{l}0.47 \\
0.25 \\
0.23\end{array}$ & $0.473^{a}$ \\
\hline$F$ & $\begin{array}{l}\text { Microcephalic } \\
\text { Normocephalic } \\
\text { Not exposed }\end{array}$ & $\begin{array}{l}0.19 \pm 0.22 \\
0.21 \pm 0.10 \\
0.11 \pm 0.07\end{array}$ & $\begin{array}{l}0.05 \\
0.15 \\
0.07\end{array}$ & $\begin{array}{l}0.33 \\
0.27 \\
0.15\end{array}$ & $0.127^{a}$ \\
\hline 0 & $\begin{array}{l}\text { Microcephalic } \\
\text { Normocephalic } \\
\text { Not exposed }\end{array}$ & $\begin{array}{l}0.22 \pm 0.21 \\
0.12 \pm 0.05 \\
0.09 \pm 0.08\end{array}$ & $\begin{array}{l}0.09 \\
0.09 \\
0.04\end{array}$ & $\begin{array}{l}0.35 \\
0.15 \\
0.14\end{array}$ & $0.135^{a}$ \\
\hline
\end{tabular}

Abbreviations: $\mathrm{HCl}$, higher confidence interval; $\mathrm{LCl}$, lower confidence interval; SD, standard deviation.

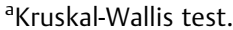


Table 3 Comparison of the slope and area measures in the frequency-following response between children with congenital infection with the Zika virus, with and without microcephaly, and children with no evidence of exposure

\begin{tabular}{|l|l|l|l|l|c|}
\hline & Groups & Mean and SD & L Cl & H Cl & $p$-value \\
\hline Slope $(\mu \mathrm{V} / \mathrm{ms})$ & Microcephalic & $0.27 \pm 0.36$ & 0.04 & 1.25 & $0.318^{\mathrm{b}}$ \\
& Normocephalic & $0.22 \pm 0.11$ & 0.06 & 0.40 & \\
& Not exposed & $0.12 \pm 0.08$ & 0.03 & 0.27 & \\
\hline Area $(\mu \mathrm{V} \times \mathrm{ms})$ & Microcephalic & $1.47 \pm 1.47$ & 0.56 & 2.38 & $0.263^{\mathrm{a}}$ \\
& Normocephalic & $0.71 \pm 0.69$ & 0.28 & 1.14 & \\
& Not exposed & $0.87 \pm 1.05$ & 0.22 & 1.52 & \\
\hline
\end{tabular}

Abbreviations: $\mathrm{HCl}$, higher confidence interval; $\mathrm{LCl}$, lower confidence interval; SD, standard deviation.

${ }^{\mathrm{a}}$ Kruskal-Wallis test.

bone-way ANOVA test.

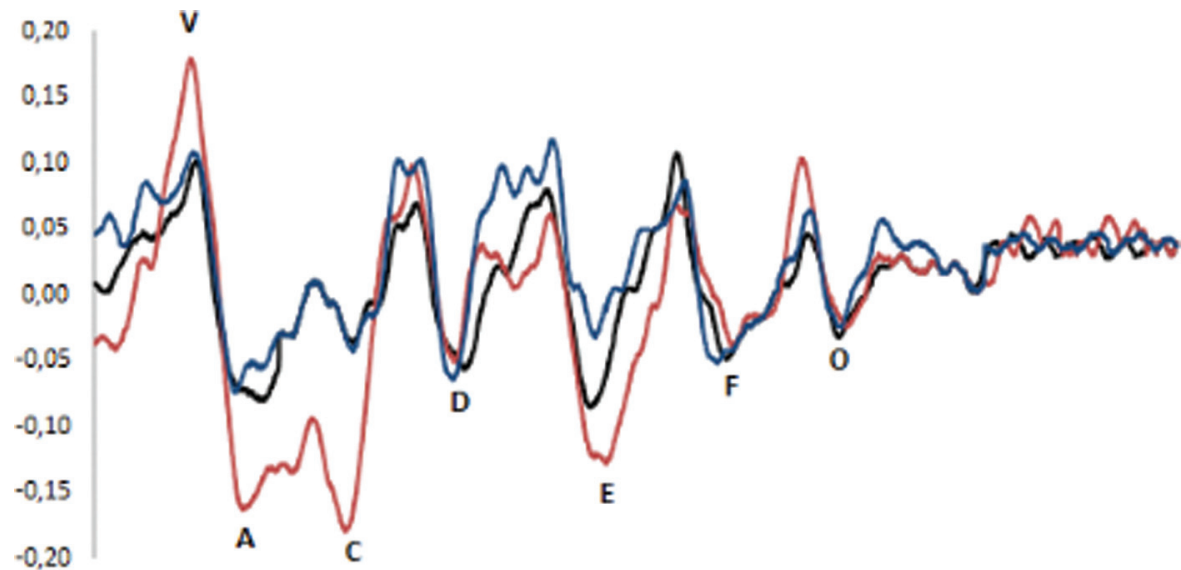

-Not Exposed - Microcephalic - Normocephalic

Fig. 1 Average waveforms of the frequency-following response exam of the groups with congenital infection with the Zika virus, with and without microcephaly, and children with no evidence of exposure.

typical development and no evidence of exposure to the infection (100\%) achieved the maximum score in the questionnaire (-Fig. 2 ).

The means of the final and category scores for each group are shown in -Table 4 . The comparison of these measures between the groups showed a significant difference for the final score means, semantic score, and expressive score of the children with microcephaly as related to normocephalic children exposed to the Zika virus group and children with typical development and no evidence of exposure to the infection group (-Table $\mathbf{5}$ ).

The correlation analysis between the FFR and LEAQ measures showed a strong negative association between the final questionnaire score and the latency measures of the A, D, F, and $\mathrm{O}$ waves and $\mathrm{C}, \mathrm{E}, \mathrm{F}, \mathrm{O}$ peak amplitudes in the group of children with microcephaly ( - Table 6 ). No correlations were

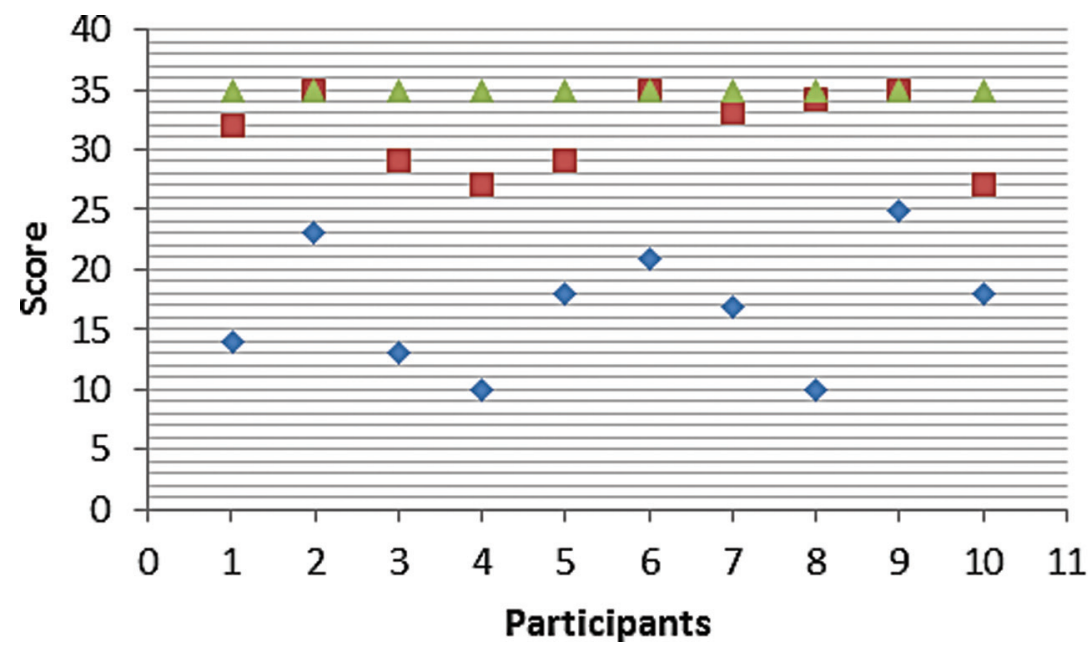

- Group 1 (microcephalic)

$\square$ Group 2 (normocephalic)

$\triangle$ Group 3 (not exposed)

Fig. 2 Individual final score in the LittlEars ${ }^{\circledR}$ questionnaire. 
Table 4 Final score, receptive score, semantic score, and expressive score in the LittlEars ${ }^{\circledR}$ questionnaire

\begin{tabular}{|l|l|l|l|}
\hline \multirow{2}{*}{ Scores } & Microcephalic & Normocephalic & Not exposed \\
\cline { 2 - 4 } & Mean and SD & Mean and SD & Mean and SD \\
\hline Final & $17 \pm 5.17$ & $32 \pm 3.31$ & $35 \pm 0$ \\
\hline Receptive & $6.30 \pm 1.05$ & $6.70 \pm 0.48$ & $7 \pm 0$ \\
\hline Semantic & $9.90 \pm 3.51$ & $17.20 \pm 2.04$ & $19 \pm 0$ \\
\hline Expressive & $0.50 \pm 0.85$ & $6.80 \pm 1.39$ & $8 \pm 0$ \\
\hline
\end{tabular}

Abbreviation: SD, Standard deviation.

Table 5 Comparison between the groups of the final score, receptive score, semantic score, and expressive score in the LittlEars ${ }^{\circledR}$ questionnaire

\begin{tabular}{|l|l|l|}
\hline Scores & Groups & $p$-value \\
\hline Final & Microcephalic x Normocephalic & $0.004^{\mathrm{a}, *}$ \\
& Microcephalic x Not exposed & $0.000^{\mathrm{a}, *}$ \\
& Normocephalic x Not exposed & $0.323^{\mathrm{a}}$ \\
\hline Receptive & Microcephalic x Normocephalic & $0.088^{\mathrm{a}}$ \\
& Microcephalic x Not exposed & \\
& Normocephalic x Not exposed & \\
\hline Semantic & Microcephalic x Normocephalic & $0.003^{\mathrm{a}, *}$ \\
& Microcephalic x Not exposed & $0.000^{\mathrm{a}, *}$ \\
& Normocephalic x Not exposed & $0.473^{\mathrm{a}}$ \\
\hline Expressive & Microcephalic x Normocephalic & $0.002^{\mathrm{a}, *}$ \\
& Microcephalic x Not exposed & $0.000^{\mathrm{a}, *}$ \\
& Normocephalic x Not exposed & $0.514^{\mathrm{a}}$ \\
\hline
\end{tabular}

${ }^{\mathrm{a}}$ Kruskal-Wallis test.

${ }^{*}=p<0.05$.

observed in the group of normocephalic children exposed to the Zika virus. In the group of children with typical development and no evidence of exposure to the infection, it was not possible to calculate the correlation coefficients because there was no variation in the questionnaire values for this group.

\section{Discussion}

The goal of the present study was to analyze the FFR results and the auditory behavior (through parental observation) of children with prenatal exposure to Zika virus infection, with and without microcephaly, and to compare them with children in the same range age with typical development and no evidence of prenatal exposure to the virus.

The children assessed in the present study with prenatal exposure to the Zika virus, with and without microcephaly, presented FFR latency, amplitude, slope, and area similar to those of children with typical development and no evidence of exposure to the infection. These findings suggest that prenatal exposure to the Zika virus does not seem to interfere with the velocity (latency), synchrony (slope), and magnitude of the neural responses (amplitude and area of the VA complex) of speech sound decoding at the brainstem auditory pathways. All those processes are critical to the adequate auditory perception of verbal sounds. ${ }^{26}$
Table 6 Correlation between the final scores in the LittlEars ${ }^{\circledR}$ questionnaire and the latency and amplitude measures in the frequency-following response in the group of children with microcephaly

\begin{tabular}{|l|l|}
\hline Final score & \\
\hline Coefficient & $-0.727^{\mathrm{b}}$ \\
\hline A latency $(\mathrm{ms})$ & $-0.747^{\mathrm{a}}$ \\
\hline D latency $(\mathrm{ms})$ & $-0.704^{\mathrm{a}}$ \\
\hline F latency $(\mathrm{ms})$ & $-0.714^{\mathrm{a}}$ \\
\hline O latency $(\mathrm{ms})$ & $-0.780^{\mathrm{a}}$ \\
\hline C amplitude $(\mu \mathrm{V})$ & $-0.743^{\mathrm{b}}$ \\
\hline E amplitude $(\mu \mathrm{V})$ & $-0.764^{\mathrm{b}}$ \\
\hline F amplitude $(\mu \mathrm{V})$ & $-0.709^{\mathrm{b}}$ \\
\hline O amplitude $(\mu \mathrm{V})$ & \\
\hline
\end{tabular}

aPearson correlation test.

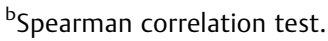

These results differ from others presented in studies that assessed children with congenital infection with another pathogen (toxoplasmosis) and CNS impairment of another origin (concussions and epilepsy), in which slower neural responses with less amplitude were found. ${ }^{26-28}$

Although there is evidence of risk of auditory damage associated with Zika virus infection, the results are not enough to understand the pathogenesis of the infection in the auditory system and its impacts on the auditory function, especially in children with clear signs of CNS changes. ${ }^{12,13}$

White-Schwoch et al. report that FFR responses are generated mainly in the mesencephalic region of the auditory pathway, suggesting that the precise and synchronous decoding of the speech stimulus in the auditory mesencephalon is necessary and sufficient to generate a robust and replicable electrophysiological response to the examination, even if the subject presents cortical changes. ${ }^{29}$

On the other hand, the findings presented here are similar to ABR-click in children with microcephaly associated with prenatal infection with Zika virus, when it normality was observed in the neuronal functions of the pons and the mesencephalon, suggesting the integrity of the auditory structures at this level of the pathway. ${ }^{30}$ Therefore, it can be suggested that prenatal infection with the Zika virus does not seem to impair the functioning of the brainstem auditory 
structures responsible for the neural processing of sounds, especially of the temporal cues of such complex stimuli as speech sounds.

However, the present study did not investigate how these children decode the spectral aspects related to the fundamental frequency and the harmonics contained in the speech stimulus. These elements should be investigated in cases of auditory perception and CNS impairment. ${ }^{27}$

The auditory cortex and mesencephalon play different roles in auditory perception. Even if brainstem fine temporal resolution is intact, it alone is not enough to properly analyze and comprehend speech at the cortical level. ${ }^{29}$ Therefore, changes in the processing of verbal signals in the cortical structures of the auditory pathway should be investigated and cannot be dismissed.

The auditory behavior report of children with exposure to the Zika virus, with and without microcephaly, seemed to present immature behavior, according to the parental observation when compared with standard references of children with normal hearing and with the group with no evidence of exposure to the infection.

Children with microcephaly had a significantly different final score when compared with the normocephalic children exposed to the Zika virus and with the children with no evidence of exposure to the infection. Also, their performance was far below the expected in relation to the reference values of the questionnaire for children with normal hearing. Their scores were compatible with the expected for children between 6 and 8 months old. ${ }^{22}$

Even though the neuropsychomotor delay caused by microcephaly can influence the behavioral auditory responses, ${ }^{31}$ impairments in the adequate physiological functioning of the cortical auditory pathway must be considered when there are changes in the brain growth of these children. Such a condition can impact the proper development of the central auditory system and, consequently, the acquisition of auditory skills.

A study by de Carvalho Leal et al. described that it is not unusual to observe, in children with congenital infection with the Zika virus, normality in the objective auditory tests, such as the brainstem auditory evoked potential (BAEP), which analyzes the lower portions of the auditory pathways and alterations in the auditory skills in behavioral responses, which suggest damages in the central auditory system. ${ }^{13}$

The analysis of question category score reinforces this supposition, observing that children with microcephaly have a mean receptive score similar to those of normocephalic children and of children with no evidence of exposure to the infection, and results significantly lower than those of these groups for the semantic and expressive scores.

The receptive score is related to the items in the questionnaire involving auditory detection and localization behaviors - attentional skills that depend on adequate temporal sound decoding (bottom-up processes). ${ }^{32}$ The semantic and expressive scores are associated with the items involving interpretation and comprehension of sound event and linguistic skill responses - specialized CNS skills closely related to the supramodal cortical hearing functions, such as cognition and language (top-down processes). ${ }^{33}$

Auditory skills associated with bottom-up processes can be preserved in children with microcephaly, supporting the electrophysiologic findings. Nevertheless, due to the cortical impairment, the performance in auditory skills that depend mainly on top-down processes can be impaired, interfering directly with the central auditory processing (CAP).

Normocephalic children exposed to the Zika virus did not present significant differences in the final and category scores when compared with the group of children with typical development and no evidence of exposure to the infection. However, a performance lower than expected was observed when compared with the reference values of the questionnaire for children with normal hearing, with a mean final score fitting the results expected for children between 22 and 23 months old. ${ }^{22}$

Normocephalic children with prenatal exposure to the Zika virus have been presenting results below the expected in the neurodevelopment of different domains, including cognition and language/communication. ${ }^{6-9}$ In the present study, 8 out of 10 children comprising this group presented complaints of delay in language acquisition and/or unintelligible speech. Also, their performance was below of what is expected in questionnaire items related to behaviors of interpretation/comprehension of sound events and linguistic skills.

These skills are associated with functions of a higher order and depend on the adequate maturation of the CNS and integration with other systems, such as cognition and language. $^{33}$ Thus, the results of the questionnaire support the evidence of changes in the cognition and language development of these children. Changes in the CAP must also be considered due to the risk of loss in the performance of auditory skills associated with top-down processes.

The answers obtained with the questionnaire reflect the parental perception of these auditory behavior of these children in response to common day-to-day stimuli. These instruments do not substitute assessments with classic standardized tests, but they can be a first step toward early identification of changes in auditory development and acquisition of auditory skills, especially in small children. ${ }^{34}$

The association between the results of auditory assessment showed that, in the group of children with microcephaly associated with Zika virus infection, there was a strong negative correlation between the final score of the questionnaire and the latency measures of FFR waves A, D, F, O and the amplitude of the $\mathrm{C}, \mathrm{E}, \mathrm{F}$, and $\mathrm{O}$ waves. This association suggests that, in this group, as the FFR latency and amplitude values increase, the final score of the questionnaire decreases.

In this group, children with severe microcephaly had the lowest final scores (-Fig. 3). This can be related to severe microcephaly being the most serious type of this condition, leading to greater delays in overall development. ${ }^{35}$ Regarding FFR with increased latency, the possibility of the severity of microcephaly interfering with the velocity of neural sound conduction in the brainstem must be considered. 


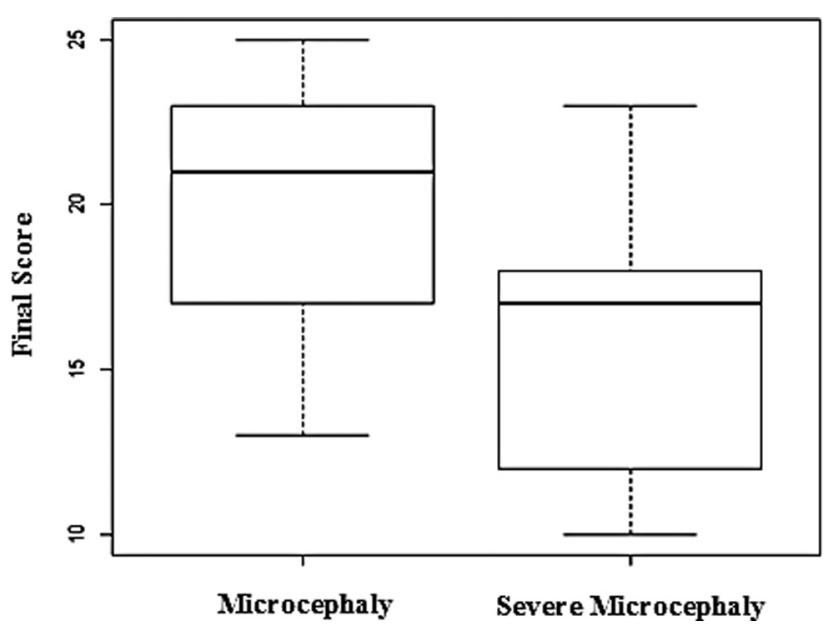

Fig. 3 Distribution of the final score in the LittlEars ${ }^{\circledR}$ questionnaire in the groups of children with microcephaly.

Even though no abnormalities in the velocity of neural conduction related to the $\mathrm{HC}$ were observed in the present study, similar to what was described by Marques Abramov et al., both studies present limitations regarding the sample size. ${ }^{30}$
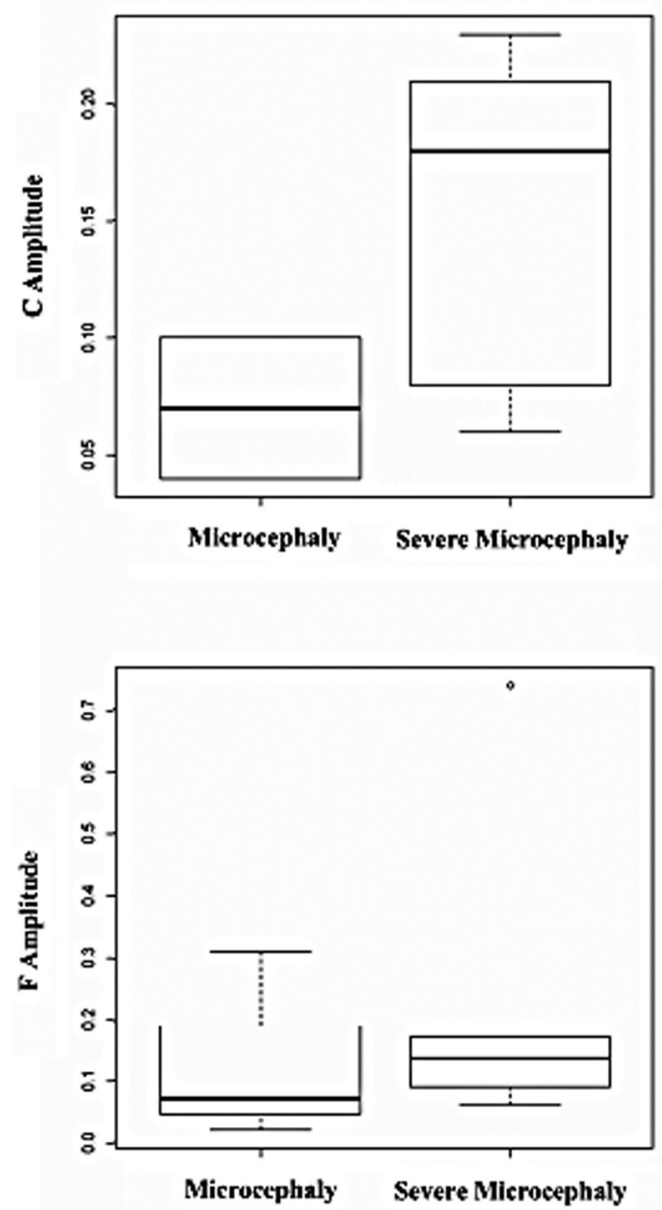

The FFR latencies are stable measures associated with the conduction velocity of an acoustic stimulus in the auditory pathways, and are directly related to axonal fibers myelinization. ${ }^{36,37}$ The delay in myelination of the neural fibers is a common finding in microcephaly associated with the Zika virus. ${ }^{3}$ Even though the results presented here indicate an adequate time of nerve conduction of sounds in these children, future studies with larger samples are necessary to better define whether the severity of the microcephaly can interfere with this process.

In the same perspective, despite the fact that no difference has been observed between the groups, the children with severe microcephaly had greater amplitude values ( - Fig. 4), which differs from the tendency observed in the correlation. The amplitudes in the FFR test reflect the magnitude of the neural activation - mechanisms that contribute to the generation of waves in the exam. ${ }^{19}$ These measures are more sensitive to variability. ${ }^{37}$

There is the possibility of a smaller $\mathrm{HC}$ influencing the amplitude responses in children with severe microcephaly due to the volume conduction effect, which takes place when there is a short distance between the electrical signal pick-up and its generating site in the auditory pathway, which can increase the amplitude of the potential. ${ }^{38}$
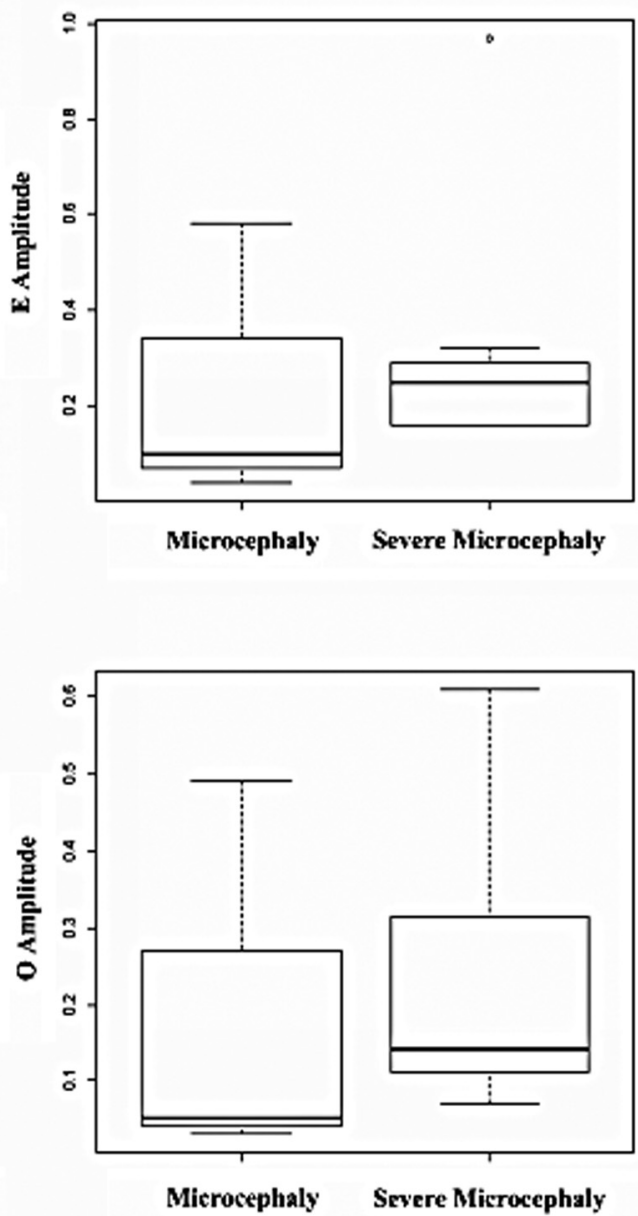

Fig. 4 Distribution of the amplitude values of the C, E, F, and O waves in the frequency-following response in the group of children with microcephaly. 
However, for this supposition, further studies using more specific analyses of the response magnitude (such as the root mean square calculation) and broader samples should be conducted. They may be able to clarify whether the amplitude measures in children with severe microcephaly actually reflect the adequate sturdiness in the neural activation for the processing of the stimulus or if the $\mathrm{HC}$ interferes with them through the volume conduction effect.

The present study analyzed, from different perspectives, the auditory function of children exposed to the Zika virus in the intrauterine period, with and without microcephaly. From the electrophysiological standpoint, prenatal exposure to Zika virus infection does not seem to interfere with the neural decoding of the temporal aspects of speech sounds in the brainstem.

On the other hand, the analysis of auditory behavior through parental observation showed that these children present signs of immaturity in auditory behavior, which suggests a delay in the auditory development and in the acquisition of auditory and linguistic skills.

Future studies with larger samples, in different moments of development and with different analysis and assessment tools, are still necessary to better define the association between prenatal exposure to the Zika virus and the outcomes of the present study.

\section{Conclusion}

Children with prenatal exposure to Zika virus infection, with and without microcephaly, presented FFR latency, amplitude, slope, and area similar to those of children with typical development and no evidence of exposure to any infection, suggesting similar patterns of neural decoding of the temporal aspects of sound speech.

The analysis of auditory behavior through the LEAQ showed that children prenatally exposed to Zika virus infection, with and without microcephaly, presented signs of an immature auditory behavior when compared with children with normal hearing - especially for children with microcephaly, who presented a significantly inferior performance compared with children with no evidence of exposure to the infection. These results suggest that prenatal exposure to Zika virus infection can interfere with the auditory development and with the acquisition of auditory and linguistic skills. Children with microcephaly final performance decrease as the FFR latency and amplitude components increase.

\section{Funding}

This study was funded by the Brazilian's National Council for Scientific and Technological Development (CNPq Universal 01/2016-420108/2016-5) and had also the support of Coordenação de Aperfeiçoamento de Pessoal de Nível Superior (CAPES) - Finance code 001.

\section{Conflict of Interests}

The authors have no conflict of interests to declare.

\section{References}

1 Tang H, Hammack C, Ogden SC, et al. Zika Virus Infects Human Cortical Neural Precursors and Attenuates Their Growth. Cell Stem Cell 2015;18(00):1067-1073

2 van der Linden V, Pessoa A, Dobyns W, et al. Description of 13 Infants Born During October 2015-January 2016 With Congenital Zika Virus Infection Without Microcephaly at Birth - Brazil. MMWR Morb Mortal Wkly Rep 2016;65(47):1343-1348

3 Aragao Mde FV, Van Der Linden V, Brainer-Lima AM, et al. Clinical features and neuroimaging (CT and MRI) findings in presumed Zika virus related congenital infection and microcephaly: Retrospective case series study. BMJ 2016;353:1-10

4 Eickmann SH, Carvalho MDCG, Ramos RCF, Rocha MÂW, Linden Vv, Silva PF. Síndrome da infecção congênita pelo vírus Zika. Cad Saude Publica 2016;32(07):1-3

5 Moore CA, Staples JE, Dobyns WB, et al. Characterizing the Pattern of Anomalies in Congenital Zika Syndrome for Pediatric Clinicians. JAMA Pediatr 2017;171(03):288-295

6 Einspieler C, Utsch F, Brasil P, et al; GM Zika Working Group. Association of Infants Exposed to Prenatal Zika Virus Infection With Their Clinical, Neurologic, and Developmental Status Evaluated via the General Movement Assessment Tool. JAMA Netw Open 2019;2(01):e187235

7 Nielsen-Saines K, Brasil P, Kerin T, et al. Delayed childhood neurodevelopment and neurosensory alterations in the second year of life in a prospective cohort of ZIKV-exposed children. Nat Med 2019;25(08):1213-1217

8 Mulkey SB, Arroyave-Wessel M, Peyton C, et al. Neurodevelopmental Abnormalities in Children with in Utero Zika Virus Exposure without Congenital Zika Syndrome. JAMA Pediatr 2020;174 (03):269-276

9 Peçanha PM, Gomes Junior SC, Pone SM, et al. Neurodevelopment of children exposed intra-uterus by Zika virus: A case series. PLoS One 2020;15(02):e0229434

10 Leal MC, Muniz LF, Ferreira TSA, et al. Hearing loss in infants with microcephaly and evidence of congenital zika virus infection Brazil, November 2015-May 2016. MMWR Morb Mortal Wkly Rep 2016;65(34):917-919

11 The Joint Committee on Infant Hearing. Year 2019 Position Statement: Principles and Guidelines for Early Hearing Detection and Intervention Programs. J Early Hear Detect Interv 2019;4(02): $1-44$

12 Barbosa Mde M, Magalhães-Barbosa Mde, Robaina JR, PrataBarbosa A, Lima Mde MT de, Cunha Ada. Auditory findings associated with Zika virus infection: an integrative review. Rev Bras Otorrinolaringol (Engl Ed) 2019;85(05):642-663. Doi: 10.1016/j.bjorlp.2019.05.014

13 de Carvalho Leal M, Ramos DS, Caldas Neto SS. Hearing Loss From Congenital Zika Virus Infection. Top Magn Reson Imaging 2019;28 (01):19-22

14 Mittal R, Fifer RC, Liu XZ. A possible association between hearing loss and Zika virus infections. JAMA Otolaryngol Head Neck Surg 2018;144(01):3-4

15 Boscariol M, Guimarães CA, Hage SR, et al. Auditory processing disorder in patients with language-learning impairment and correlation with malformation of cortical development. Brain Dev 2011;33(10):824-831

16 Sobreira Ade O, Capo BM, Santos TS. Dos, Gil D. Desenvolvimento de fala e linguagem na deficiência auditiva: relato de dois casos. Rev CEFAC 2015;17(01):308-317

17 Gouveia AS, Oliveira MMF, Goulart AL, Azevedo MF, Perissinoto J Development of speech and hearing skills in prematures adequate and small for gestational age: chronological age between 18 and 36 months. CoDAS 2020;32(04):e20180275

18 Kraus N, Anderson S, White-Schwoch T. The Frequency-Following Response: A Window into Human Communication. In: Kraus N, Anderson S, White-Schwoch T, Fay RR, Popper AN, editors. 
Springer Handbook of Auditory Research [Internet]. 2017:1-15 Available from: http://www.springer.com/series/2506

19 Skoe E, Kraus N. Auditory brain stem response to complex sounds: a tutorial. Ear Hear 2010;31(03):302-324

20 American Academy of Audiology. Diagnosis, treatment and management of children and adults with central auditory processing disorder. Clin Pract Guidel 2010;(August)1-51

21 American Speech-Language-Hearing Association (ASHA). (Central) auditory processing disorders. 2005

22 Coninx F, Weichbold V, Tsiakpini L, et al. Validation of the LittlEARS((R)) Auditory Questionnaire in children with normal hearing. Int J Pediatr Otorhinolaryngol 2009;73(12):1761-1768

23 Persson A, Miniscalco C, Lohmander A, Flynn T. Validation of the Swedish version of the LittlEARS ${ }^{\circledR}$ Auditory Questionnaire in children with normal hearing - a longitudinal study. Int J Audiol 2019;58(10):635-642. Doi: 10.1080/14992027.2019.1621397 [Internet]

24 World Health Organization. WHO | Screening, assessment and management of neonates and infants with complications associated with Zika virus exposure in utero. Who [Internet] 2016;(August). Available from: http://www.who.int/csr/resources/publications/ zika/assessment-infants/en/

25 Liu H, Jin X, Li J, et al. Early auditory preverbal skills development in Mandarin speaking children with cochlear implants. Int J Pediatr Otorhinolaryngol 2015;79(01):71-75. Doi: 10.1016/j. ijporl.2014.11.010 [Internet]

26 Ferreira L, Valadão Mda S, Skarzynski PH, Sanfins MD, Biaggio EPV. Effect of congenital toxoplasmosis on the encoding of speech in infants. Int J Pediatr Otorhinolaryngol 2019;2020:129

27 Kraus N, Thompson EC, Krizman J, Cook K, White-Schwoch T, LaBella CR. Auditory biological marker of concussion in children. Sci Rep 2016;6:39009. Doi: 10.1038/srep39009

28 Elkabariti RH, Khalil LH, Husein R, Talaat HS. Speech evoked auditory brainstem response findings in children with epilepsy.
Int J Pediatr Otorhinolaryngol 2014;78(08):1277-1280. Doi: 10.1016/j.ijporl.2014.05.010[Internet]

29 White-Schwoch T, Anderson S, Krizman J, Nicol T, Kraus N. Case studies in neuroscience: subcortical origins of the frequencyfollowing response. J Neurophysiol 2019;122(02):844-848

30 Marques Abramov D, Saad T, Gomes-Junior SC, et al. Auditory brainstem function in microcephaly related to Zika virus infection. Neurology 2018;90(07):e606-e614

31 Rosa Bda S, Silva JF, Santos M, Lewis DR. Avaliação audiológica em criança com microcefalia pelo zika vírus: estudo de caso. Distúrb Comun 2018;30(02):357

32 Picton T. Hearing in time: evoked potential studies of temporal processing. Ear Hear 2013;34(04):385-401

33 Frota S. Fundamentos Teóricos do Sistema Auditivo Central. In: Marchesan IQ, Silva HJ, Tomé MC, editors. Tratado das Especialidades em Fonoaudiologia. 1st ed. Rio de JaneiroROCA2014: 848-53

34 de Souza IMP, de Carvalho NG, Plotegher SDCB, Colella-Santos MF, do Amaral MIR. Triagem do processamento auditivo central: contribuições do uso combinado de questionário e tarefas auditivas. Audiol Commun Res 2018;23:1-8

35 Centers for Disease Control and Prevention (CDC) Facts about Microcephaly [Internet]. 2017 [cited 2020 Jun 4]. p. 1-3. Available from: https://www.cdc.gov/ncbddd/birthdefects/microcephaly. htm

36 Long P, Wan G, Roberts MT, Corfas G. Myelin development, plasticity, and pathology in the auditory system. Dev Neurobiol 2018;78(02):80-92

37 Zakaria MN, Jalaei B. Test-retest reliability of speech-evoked auditory brainstem response in healthy children at a low sensation level. Int J Pediatr Otorhinolaryngol 2017;102:28-31. Doi: 10.1016/j.ijporl.2017.08.033

38 Rutkove SB. Introduction to volume conduction. Clin Neurophysiol Prim. 2007;C:43-53 